An Introduction to Digital Logic 
Other titles in Electrical and Electronic Engineering

B. A. Gregory: An Introduction to Electrical Instrumentation

P. and A. Lynn: An Introduction to the Analysis and Processing of Signals

A. G. Martin and F. W. Stephenson: Linear Microelectronic Systems

G. Williams: An Introduction to Electrical Circuit Theory 


\section{An Introduction to Digital Logic}

\section{A. Potton}

\section{Principal Lecturer}

School of Electronic and Electrical Engineering City of Leicester Polytechnic 
(C) A. Potton 1973

All rights reserved. No part of this publication may be reproduced or transmitted, in any form or by any means, without permission.

First published 1973 by

THE MACMILLAN PRESS LTD

London and Basingstoke

Associated Companies in New York Dublin

Melbourne Johannesburg and Madras

SBN 333146794

ISBN 978-1-349-01839-0 ISBN 978-1-349-01837-6 (eBook)

DOI 10.1007/978-1-349-01837-6

The paperback edition of this book is sold subject to the condition that it shall not, by way of trade or otherwise, be lent, resold, hired out, or otherwise circulated without the publisher's prior consent, in any form of binding or cover other than that in which it is published and without a similar condition including this condition being imposed on the subsequent purchaser. 


\section{Contents}

$\begin{array}{ll}\text { Preface } & \text { ix }\end{array}$

1 COMBINATIONAL LOGIC CIRCUITS

1.1 Combinational binary logic circuits 2

1.2 The NOT gate 3

1.3 Truth tables 5

1.4 Positive and negative logic 5

$\begin{array}{lll}1.5 & \text { Noise immunity } & 6\end{array}$

1.6 NAND and NOR gates 7

1.7 The NOR operation 8

$\begin{array}{ll}1.8 \text { The NAND operation } & 9\end{array}$

1.9 The NAND-NOR relationship 10

1.10 AND and OR gates 11 .

$\begin{array}{ll}1.11 \text { The AND operation } & 11\end{array}$

$\begin{array}{ll}1.12 \text { The OR operation } & 11\end{array}$

$\begin{array}{ll}1.13 \text { The AND-OR relationship } & 12\end{array}$

$\begin{array}{ll}1.14 \text { Interconnection of gates } & 13\end{array}$

$\begin{array}{ll}\text { Problems } & 15\end{array}$

2 BOOLEAN ALGEBRA 17

$\begin{array}{lll}2.1 & \text { George Boole } & 17\end{array}$

$\begin{array}{ll}2.2 & \text { Boolean variables } \\ 2.3 & 18\end{array}$

$\begin{array}{ll}2.3 \text { Boolean inversion } & 18\end{array}$

$\begin{array}{lll}2.4 & \text { The boolean AND operation } & 18\end{array}$

$\begin{array}{ll}2.5 & \text { The boolean OR operation } \\ 2.6 & 18\end{array}$

$\begin{array}{lll}2.6 & \text { The NAND operation } & 18\end{array}$

$\begin{array}{ll}2.7 & \text { The NOR operation } \\ 2.8 & 18\end{array}$

$\begin{array}{lll}2.8 & \text { Boolean expressions and truth tables } & 19\end{array}$

$\begin{array}{ll}2.9 \text { Simplification of boolean expressions } & 20\end{array}$

$\begin{array}{ll}2.10 \text { Summary of boolean relationships } & 21\end{array}$

$\begin{array}{ll}\text { Problems } & 22\end{array}$

Bibliography $\quad 23$ 
3.1 A simple design example 24

3.2 An additional variable 25

3.3 A second design example 27

3.4 An equivalence system 30

$\begin{array}{ll}\text { Problems } & 32\end{array}$

4 KARNAUGH MAPS $\quad 34$

4.1 Looping two cells 36

4.2 The Karnaugh map technique $\quad 37$

4.3 Looping larger groups of cells 38

4.4 Further cell looping techniques 39

4.5 Looping cells containing 0's 41

4.6 Karnaugh maps for NAND-NOR logic 41

4.7 Design example 43

4.8 A second example $\quad 45$

4.9 'Don't care' situations 46

4.10 Minimisation with functions of more than four variables 48 Problems $\quad 48$

Bibliography $\quad 49$

5 BISTABLE SYSTEMS

5.1 The R-S flip-flop 50

5.2 Discrete component circuits $\quad 52$

5.3 The clocked R-S flip-flop 53

5.4 Counting elements 54

5.5 The type D flip-flop 54

5.6 The master-slave technique 55

5.7 The J-K flip-flop 55

5.8 Integrated circuit bistable elements 57

Problems $\quad 57$

Bibliography $\quad 59$

6 COUNTERS AND REGISTERS $\quad 60$

6.1 Storage and shift registers 60

6.2 Parallel and serial input and output of data 62

6.3 Ripple-through counters 63 
$\begin{array}{lll}6.4 & \text { Frequency division } & 63\end{array}$

$\begin{array}{lll}6.5 & \text { Binary counters } & 64\end{array}$

6.6 Modification of the counting period 66

6.7 A scale of six binary counter 66

$\begin{array}{lll}6.8 & \text { A scale of five counter } & 67\end{array}$

6.9 A scale of twelve counter 68

$\begin{array}{ll}\text { Problems } & 70\end{array}$

$\begin{array}{ll}\text { Bibliography } & 70\end{array}$

7 SYNCHRONOUS COUNTERS

$\begin{array}{lll}7.1 & \text { A simple two-stage counter } & 71\end{array}$

$\begin{array}{ll}7.2 \text { A four-stage counter } & 72\end{array}$

$\begin{array}{lll}7.3 & \text { Variable sequence counters } & 78\end{array}$

$\begin{array}{ll}\text { Problems } & 81\end{array}$

Bibliography $\quad 82$

8 SIMPLE SEQUENTIAL LOGIC SYSTEMS $\quad 83$

8.1 An electronic combination lock 83

$\begin{array}{ll}8.2 \text { Lift control systems } & 85\end{array}$

8.3 Timing sequences $\quad 88$

$\begin{array}{ll}8.4 & \text { Integrated circuit decoders }\end{array}$

$\begin{array}{ll}8.5 & \text { Decoding noise }\end{array}$

$\begin{array}{ll}\text { Problems } & 94\end{array}$

9 BINARY ARITHMETIC OPERATIONS 96

$\begin{array}{lll}9.1 & \text { Binary adders } & 96\end{array}$

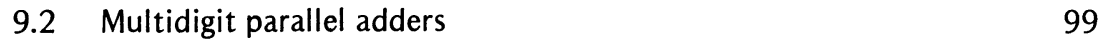

$\begin{array}{ll}9.3 \text { Carry-bypass adders } & 101\end{array}$

$\begin{array}{lll}9.4 & \text { Serial adders } & 102\end{array}$

$\begin{array}{lll}9.5 & \text { Signed binary numbers } & 103\end{array}$

$\begin{array}{ll}\text { 9.6 Generation of complements } & 104\end{array}$

$\begin{array}{lll}9.7 & \text { Binary subtraction } & 106\end{array}$

$\begin{array}{lll}9.8 & \text { Binary multiplication } & 107\end{array}$

$\begin{array}{lll}9.9 \text { Binary division } & 109\end{array}$

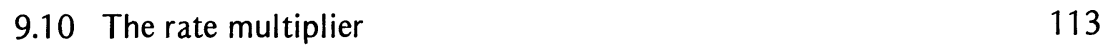

$\begin{array}{ll}\text { Problems } & 116\end{array}$

$\begin{array}{ll}\text { Bibliography } & 117\end{array}$ 
10.1 Integrated circuit families 118

10.2 Packaging of digital integrated circuits 118

$\begin{array}{ll}10.3 \text { Practical system development } & 119\end{array}$

10.4 Digital circuit parameters 120

$\begin{array}{ll}10.5 \text { Logic levels } & 120\end{array}$

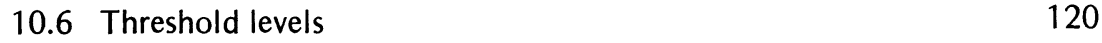

$\begin{array}{ll}10.7 \text { Noise margin } & 120\end{array}$

10.8 Fan out 121

$\begin{array}{ll}10.9 \text { Propagation delay time } & 121\end{array}$

10.10 Wired logic 122

10.11 Resistor-transistor logic (R.T.L.) 122

10.12 Diode-transistor logic (D.T.L.) 123

10.13 Transistor-transistor logic (T.T.L.) 124

10.14 Emitter coupled logic (E.C.L.) 125

10.15 Metal oxide semiconductor integrated circuits (M.O.S.) 126

10.16 Complementary MOS logic (C.M.O.S.) 128

$\begin{array}{ll}\text { Bibliography } & 131\end{array}$

$\begin{array}{ll}\text { APPENDIXES } & 132\end{array}$

Appendix A Systems of Numeration $\quad 132$

Appendix B Logic Symbols $\quad 140$ 


\section{Preface}

During the past few years, we have seen an unprecedented expansion in the applications of electronic techniques. It is no accident that a large part of this expansion has involved systems using digital techniques. Undoubtedly, economic factors provide the major reasons for this. Digital systems which, even a few years ago, would occupy weeks of an engineer's time in the design phase can now be bought as low cost, 'off the shelf' integrated circuits. As a result of this the engineer can now contemplate the design of systems which would previously have been considered totally uneconomic and hopelessly complex. A further consequence of the expansion of digital electronic techniques has been that engineers in fields not traditionally associated with electronics have become aware of the potentialities and power of these techniques.

The aim of this book is to introduce the reader to electronic digital systems and assist him to develop the techniques necessary for the understanding and design of such systems. The book is essentially an introductory text, no previous knowledge of digital systems or indeed of general electronics being assumed. From time to time in the text, reference is made to the discrete component circuit form of some digital system elements. Particular examples are the NOT and NOR gates in chapter 1 and the R-S bistable circuit in chapter 5 . The brief explanations which accompany these circuits are intended to assist readers who have some background knowledge of electronic circuits and devices. Such a background is not essential to the general understanding of the text however and readers who have no previous knowledge of the subject may accept the description of the characteristics of the circuit without being unduly worried about the actual details of the circuit action.

The book should prove suitable for use as a text for first and second year HND and BSc engineering students at Polytechnics, Universities and Technical Colleges. Much of the material will also be useful to students pursuing the more advanced stages of some technician level courses such as the HNC in electrical engineering.

The common types of logic gates are introduced in chapter 1 of the text as are the ideas of positive and negative logic. The action of gates and logic systems is described in this chapter mainly by the use of truth tables.

Chapter 2 provides a brief introduction to boolean algebra. In a text of this kind, it is neither essential nor desirable to include a detailed treatment of boolean algebra with full mathematical rigour. The object of chapter 2 is to establish the basic concept of two-state variables and accustom the reader to the boolean manner of describing logical relationships. A list of some useful boolean relationships is included at the end of this chapter for completeness. There is no suggestion that these relationships should be committed to memory before proceeding with the remainder of the text.

Chapter 3 is perhaps unusual in that it discusses design techniques before the reader has been introduced to logical map methods. The purpose of this is twofold; 
firstly to provide the reader with an incentive to persevere with the study of the techniques which assist the design of logic systems, and secondly, to accustom the reader to the use of boolean terminology.

Logical maps are dealt with in chapter 4 and are used in the remainder of the text when simplification of a logical function is required.

Chapters 5 to 8 cover the more formal aspects of sequential logic systems starting with bistable elements in chapter 5 , proceeding to registers and ripplethrough counters in chapter 6 and synchronous counters in chapter 7. Chapter 8 deals with a selection of practical design problems which require the use of sequential logic elements for their solution.

In chapter 9 systems are described for performing arithmetic operations. It was felt that a chapter of this type merited inclusion if only because an introductory text on logic design is often used as a preliminary to a more detailed study of computer hardware.

Chapter 10 contains a review of important logic element parameters. Also included in this chapter are details of the important ranges of currently available integrated circuits. As has been said previously, the reader with no formal electronics background may choose to pass over the details of the circuit operation of particular logic families although the importance of the various parameters should be understood.

My grateful thanks are extended to Dorothy, without whose understanding, tolerance and superlative typing this book would never have been finished. In conclusion, the author would welcome any useful comments or criticism on the material presented in this modest text. 